Original Research Paper

\title{
Peningkatan Keaktifan dan Kemampuan Kerjasama Siswa Kelas VI SDN 16 Mataram Pada Mata Pelajaran Pendidikan Kewarganegaraan Melalui Penerapan Strategi Pembelajaran Portofolio
}

\author{
Mubassyiratul Uyuni ${ }^{1}$ \\ ${ }^{1}$ Sekolah Dasar Negeri 16 Mataram, Indonesia.
}

*Corresponding Author:

Mubassyiratul Uyuni,

Sekolah Dasar Negeri 16

Mataram, Indonesia;

Email:

ayoeazkirania@gmail.com

\begin{abstract}
Abstrak: Upaya meningkatkan keaktifan dan kemampuan kerjasama pada siswa kelas VI SDN 16 Mataram melalui penerapan strategi pembelajaran portofolio merupakan permasalahan dari penelitian ini. Tujuannya adalah 1) Menemukan upaya peningkatan kemampuan guru dalam mengelola kegiatan pembelajaran pada mata pelajaran Pkn di kelas VI SDN 16 Mataram melalui implementasi strategi pembelajaran portofolio. 2) Menemukan upaya peningkatan keaktifan belajar siswa dalam proses pembelajaran pada mata pembelajaran PKn melalui implementasi strategi pembelajaran portofolio di kelas VI SDN 16 Mataram. 3) Menemukan upaya peningkatan keterampilan kerjasama dalam menyelesaikan tugas kelompok yang tercermin dari produk hasil pemecahan masalah pada mata pelajaran PKn melalui implementasi strategi pembelajaran portofolio. Penelitian ini dilakukan di Sekolah Dasar Negeri 16 Mataram dengan metode penelitian tindakan kelas yang dilaksanakan selama dua siklus, setiap siklus melalui tahapan perencanaan, pelaksanaan, observasi dan refleksi. Analisis data dilakukan dengan merefleksi hasil pengamatan dan tingkat penguasaan kompetensi dasar yang dijabarkan menjadi indicator pencapaian hasil belajar oleh siswa selama pelaksanaan tindakan. Hasil penelitian ini menunjukkan bahwa penerapan strategi pembelajaran portofolio dapat meningkatkan keaktifan dan kemampuan kerjasama siswa kelas VI semester 1 SDN 16 Mataram pada mata pelajaran Pendidikan Kewarganegaraan $(\mathrm{PKn})$ yang diperlihatkan dengan kemampuan sebagian besar siswa dalam mengajukan pertanyaan, memberikan respon, mengajukan gagasan, mengumpulkan data, serta membuat portofolio dokumen dan portofolio tayangan dengan kerjasama yang intens, baik antar anggota kelompok maupun antar kelompok dengan kualitas yang baik.
\end{abstract}

Kata Kunci: Keaktifan Siswa, Kemampuan Kerjasama Siswa, Strategi Pembelajaran Fortopolio

\section{Pendahuluan}

Dewasa ini tengah terjadi perubahan paradigma baru dalam bidang pendidikan yang ditandai dengan perubahan pemikiran tentang hakikat pembelajaran. Hakikat pembelajaran saat ini mengalami perubahan dari pembelajaran konvensional menuju pembelajaran konstekstual. Pembelajaran konvensional menempatkan guru sebagai titik sentral dalam setiap kegiatan pembelajaran dan menjadi satu-satunya sumber belajar. Sehingga yang aktif hanya guru, siswa pasif. Sedangkan pembelajaran kontekstual menempatkan guru sebagai pasilitator dan motivator. Orientasi kegiatan pembelajaran adalah siswa.

Perubahan paradigma pembelajaran tersebut tentunya tidak hanya pada mata pelajaran tertentu, tapi untuk semua mata pelajaran termasuk pelajaran pendidikan kewarganegaraan (PKn). Mata pelajaran Pkn merupakan mata pelajaran yang berfokus pada pembentukan warga Negara yang memahami dan mampu melaksanakan hak-hak dan kewajibannya untuk menjadi warga Negara Indonesia yang cerdas, trampil dan berkarakter sebagaimana diamanatkan oleh Pancasila dan UUD 1945 (Depdiknas, 2006). Melalui mata pelajaran 
PKn siswa diharapkan memiliki kompetensi: (1) berfikir kritis, rasional dan kreatif dalam menanggapi isu kewarganegaraan, (2) berpartisipasi secara aktif dan bertanggung jawab dalam kehidupan masyarakat, bangsa dan Negara, serta anti korupsi, (3) berinteraksi dengan bangsa-bangsa lain secara langsung atau tidak langsung dengan memanfaatkan tekhnologi informasi dan komunikasi.

Pendidikan Kewarganegaraan (PKn) sebagai salah satu mata pelajaran yang diajarkan di sekolah dengan paradigma barunya mensyaratkan pembelajaran yang memuat komponen penegtahuan, keterampilan dan disposisi kepribadian warga Negara yang fungsional dalam kehidupan masyarakat. Dalam hal ini, Azra (2003) mengemukakan bahwa kegiatan pembelajaran PKn hendaknya didasarkan pada pandangan humanistic yang berlandaskan pada asumsi bahwa siswa adalah manusia yang mempunyai potensi dan karakteristik sebagai subyek sekaligus sebagai obyek pembelajaran, sementara guru diposisikan sebagai pasilitator dan mitra dialog siswa. Sedangkan materi pembelajaran disusun berdasarkan kebutuhan dasar (basic need) siswa, bersifat fleksibel, dinamis dan fenomenologis sehingga materi tersebut bersifat konstektual dan memiliki relefansi dengan tuntutan dan perubahan social. Implikasi dari paradigma pembelajaran humanistic tersebut, siswa dimungkinkan memiliki kreativitas yang tinggi, kemandirian, dan sikap toleransi yang tinggi, karena dalam proses pembelajaran telah tumbuh iklim yang demokratis

Berdasarkan karakteristik dan kompetensi yang diharapkan dari mata pelajaran PKn tersebut, maka dalam proses pembelajaran hendaknya dapat membantu siswa dalam mengembangkan potensi yang dimiliki, baik potensi kognitif, efektif maupun psikomotor agar mampu menjadi warga Negara yang mengetahui, memahami, menyikapi dan berprilaku sesuai dengan hak dan kewajibannya sebagai warga Negara.

Untuk mencapai harapan tersebut, maka guru dituntut memiliki kemampuan dalam merancang dan melaksanakan suatu kegiatan pembelajaran yang dapat meningkatkan keaktifan siswa melalui berbagai kegiatan seperti bertanya, mengajukan gagasan, mencari informasi dari berbagai sumber, mengumpulkan data, mengamati dan sejumlah kegiatan lainnya. Namun demikian untuk mengembangkan proses pembelajaran tersebut bukanlah sesuatu yang mudah untuk dilakukan.

Berdasarkan hasil pengamatan dan wawancara yang kami lakukan dengan guru dan siswa di SDN 16 Mataram khusunya kelas VI semester 1 ada beberapa masalah yang dihadapi dalam proses pembelajaran, baik oleh guru maupun siswa. Masalah yang dihadapi siswa antara lain (1) rendahnya partisipasi aktif siswa dalam proses pembelajaran, (2) kurangnya kemampuan dan tanggung jawab siswa dalam mengerjakan baik secara individu maupun kelompok, (3) rendahnya keaktifan siswa dalam mengerjakan tugas yang diberikan guru. Sedangkan masalah yang dihadapi guru dalam proses pembelajaran PKn antara lain : (1) kurangnya pemahaman guru terhadap konteks mata pelajaran, yang menganggap $\mathrm{PKn}$ di SD hanya menekankan pada kemampuan menghapal konsep tanpa harus memberikan pengalaman belajar yang aplikatif, (2) kurangnya pemahaman guru terhadap pentingnya keaktifan dan kemampuan kerjasama siswa dalam proses pembelajaran.

Masalah-masalah yang dihadapi, baik oleh siswa maupun guru sebagaimana di uraikan di atas berdasarkan wawancara yang kami lakukan, secara umum lebih disebabkan karena guru memang tidak mendesain kegiatan pembelajaran yang dapat meningkatkan keaktifan dan kemampuan kerjasama. Guru selama ini dalam proses pembelajaran hanya menggunakan metode ceramah dan menempatkan siswa hanya sebagai obyek pembelajaran semata, akibatnya keaktifan dan kemampuan kerjasama siswa terhambat atau tidak berkembang secara optimal.

Berdasarkan tuntutan paradigma dan permasalahan di atas, maka kebutuhan tentang pentingnya upaya peningkatan keaktifan dan kemampuan kerjasama siswa melalui penerapan strategi pembelajaran portofolio mendesak dilakukan karena salah satu strategi pembelajaran yang dapat dikembangkan dalam Pembelajaran PKn adalah strategi pembelajaran portofolio. Portofolio dalam pembelajaran PKn merupakan kumpulan informasi yang tersusun dengan baik yang menggambarkan rencana kelas siswa berkenaan dengan isu kebijakan politik yang telah diputuskan untuk dikaji, baik dalam kelompok kecil maupun kelas secara keseluruhan. Portofolio kelas berisi bahan-bahan seperti pernyataan-pernyataan 
tertulis, peta, grafik, photografi, dan karya seni asli (Winataputra \& Udin, 2003)

Portofolio dalam pembelajaran PKn yang dimaksud adalah kumpulan pekerjaan, hasil karya, maupun informasi-informasi yang tersusun dengan baik dengan maksud tertentu dan terpadu berdasarkan ketentuan dan petunjuk yang telah telah ditetapkan. Dengan penerapan strategi pembelajaran portofolio maka kegiatan pembelajaran lebih berfokus pada siswa, memposisikan siswa sebagai insan yang harusd diberdayakan, serta memberikan pengalaman langsung melalui belajar praktik empiriK guna meningkatkan parisipasi, tanggung jawab, dan keaktifan dan kemampuan kerjasama siswa sesuai dengan konsep dan prinsip yang ada dalam pendidikan kewarganegaraan $(\mathrm{PKn})$.

\section{Metode}

Penelitian ini ini merupakan penelitian tindakan kelas yang lazim disebut claasroom action research. Rancangan model penelitian tindakan kelas ini adalah model spiral atau siklus dari Kemmis dan Taggart (1992) karena pada awal pelaksanaan tindakan ditemukan adanya kekurangan, kemudian dilakukan perencanaan dan pelaksanaan tindakan perbaikan pada siklus berikutnya sehingga target yang diinginkan tercapai.

Penelitian ini dilaksanakan di SDN 16 Mataram, khususnya pada siswa kelas VI semester 1 selama 5 bulan (Juni-Oktober 2017). Pertimbangannya adalah bahwa dalam proses pembelajaran selama ini menunjukkan tingkat keaktifan yang rendah, serta kurangnya kemampuan bekerjasama dalam menyelesaikan tugas atau pekerjaan yang diberikan guru, yang disebabkan oleh belum optimalnya proses pembelajaran yang dilakukan guru, khususnya terkait penerapan strategi pembelajaran yang masih menggunakan pola lama yang menempatkan siswa hanya sebagai obyek pembelajaran.

Adapun indikator
pembelajaran, mata pelajaran PKn yang
menggunakan strategi pembelajaran portofolio
adalah: 1) dilihat dari pelaksanaan pembelajaran
(tindakan), pembelajaran mata pelajaran PKn yang
menggunakan strategi pembelajaran portofolio
dikatakan berhasil jika: secara kualitatif
pelaksanaan pembelajaran lebih berfokus pada

siswa, baik pada tahap pendahuluan, kegiatan inti, penutup, pengelolaan waktu, dan pengelolaan kelas. Secara kuantitatif, minimal $75 \%$ dari keseluruhan unsur tersebut pada kategori baik berdasarkan kajian dokumen dan hasil observasi atau minimal rata-rata capaian pada keseluruhan unsur tersebut pada kategori baik, 2) dilihat dari keaktifan siswa, pembelajaran mata-mata pelajaran PKn yang menggunakan strategi pembelajaran portofolio dikatakan berhasil jika: secara kualitatif menunjukkan siswa aktif meliputi: mengerjakan tugas kelompok secara aktif, berlatih melakukan keterampilan kooperatif, aktif mempresentasikan hasil kerja. Secara kuantitatif terlihat pada pemenuhan keseluruhan unsur dimaksud pada kategory baik berdasarkan hasil pengamatan, 3) dilihat dari kemampuan kerjasama (kooperatif): pembelajaran mata pelajaran PKn yang menggunakan strategi pembelajaran portofolio dikatakan berhasil jika keterampilan kooperatif siswa meningkat setelah tindakan, khususnya pada kemampuan memberikan dan menghargai kontribusi, dan tanggung jawab dalam melaksanakan tugas memenuhi kategori baik, 4) dilihat dari tingkat penguasaan kompetensi oleh siswa, pembelajaran mata pelajaran PKn yang menggunakan strategi pembelajaran portofolio dikatakan berhasil jika minimal $75 \%$ dari keseluruhan siswa mencapai skor penguasaan kompetensi dasar 75 yang tercermin dari produk hasil belajar pada kategori baik.

Sesuai dengan jenis penelitian yang dipilih, yaitu penelitian tindakan, maka penelitian ini menggunakan model penelitian tindakan dari Kemmis dan Taggart (1992), yaitu berbentuk spiral dari sklus yang satu ke siklus yang berikutnya. Setiap siklus meliputi planning (rencana), action (tindakan), observation (pengamatan), dan reflection (refleksi). Langkah pada siklus berikutnya adalah perncanaan yang sudah direvisi, tindakan, pengamatan, dan refleksi. Sebelum masuk pada siklus 1 dilakukan tindakan pendahuluan yang berupa identifikasi permasalahan. Siklus spiral dari tahap-tahap penelitian tindakan kelas dapat dilihat pada gambar berikut: 


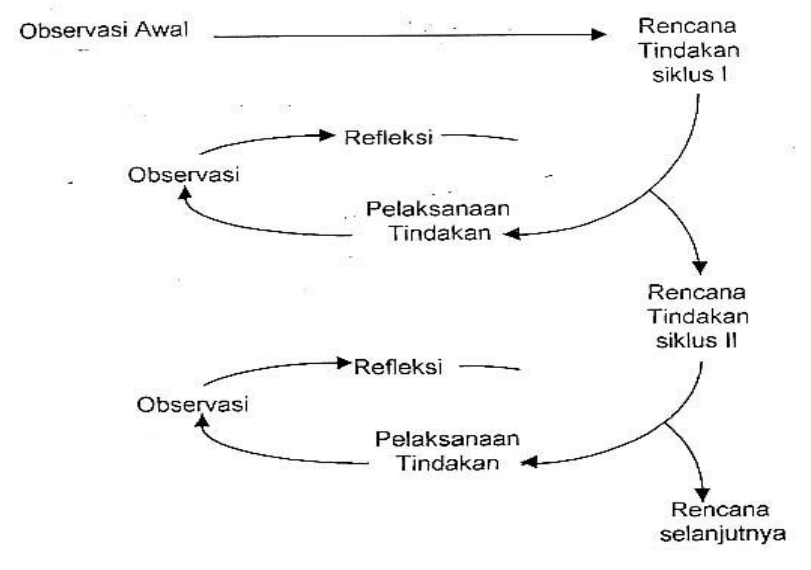

Gambar 1. Alur Penelitian Tindakan

Analisis data dalam penelitian ini adalah merefleksi hasil pengamatan dan tingkat penguasaan kompetensi dasar yang dijabarkan menjadi indicator pencapaian hasil belajar oleh siswa selama pelaksanaan tindakan.Artinya tim peneliti secara kolaboratif melihat, Mengkaji, dan mempertimbangkan dampak atau hasil tindakan baik terhadap proses maupun hasil belajar. Untuk mengukur dan memudahkan pemberian makna pada hasil refleksi terhadap hasil pengamatan akan digunakan tekhnik analisis kualitatif, melalui tiga alur kegiatan sebagaimana yang dikemukakan oleh Miles dan Huberman (1984), yaitu: (1) reduksi data, (2) penyajian data, (3) penarikan simpulan atau verifikasi.

Untuk data yang bersifat kuantitatif akan dianalisis dengan menggunakan tekhnik deskriptif kuantitatif yaitu tekhnik analisis data dengan menggunakan paparan sederhana, baik menggunakan jumlahan maupun persentase. (Suharsimi Arikunto, 1989). Untuk melihat tingkat kemampuan guru dalam mengelola kegiatan pembelajaran, digunakan kriteria: Skor 1,00 - 1,99 = tidak baik, skor 2,00 - 2,99= kurang baik, skor $3,00-3,49=$ cukup baik, dan skor 3,50 - 4,00 = baik. Untuk melihat kecendrungan tingkat keaktifan dan kemampuan kerjasama siswa selama proses pembelajaran, digunakan kriteria rata-rata capaian: skor $0,00-1,00$ : rendah, skore $1,01-2,00$ : cukup, dan skore 2,01 - 3,00 : baik. Untuk melihat capaian dalam bentuk persentase skor, digunakan kriteria: $80-100=$ baik sekali, $65-79=$ baik, $55-64=$ cukup, $45-54=$ kurang, dan $0-44=$ sangat kurang.

\section{Hasil dan Pembahasan}

Proses pembelajaran dengan penerapan strategi pembelajaran portofolio guna meningkatkan keaktifan dan kemampuan kerjasama siswa berlangsung 2 siklus, masing-masing siklus terdiri dari tahapan-tahapan, yaitu: tahap perencanaan, tindakan, diagnosis/observasi dan tahap refleksi/evaluasi. Berdasarkan implementasi siklus diperoleh data sebagai berikut:

\section{Siklus Pertama}

Siklus ini dilaksanakan mulai hari Jum'at tanggal 12 Agustus sampai tanggal 16 September 2017. Pada siklus ini, seluruh tahapan pembelajaran portofolio belum dapat dilaksanakan sebagaimana mestinya, yaitu mulai dari identifikasi masalah secara berkelompok yang disusun dalam bentuk tema, presentasi sekaligus promosi oleh setiap kelompok terkait masalah yang ditawarkan untuk dikaji kelas dengan memaparkan berbagai penyebab, akibat dan kemungkinan solusi yang dapat ditawarkan untuk mengatasi masalah tersebut, sampai kemudian dilanjutkan pemilihan satu masalah untuk dikaji kelas yang merupakan pilihan terbanyak siswa dari kesemua masalah yang telah ditawarkan oleh setiap kelompok. Hal ini terjadi karena guru belum mengarahkan siswa sesuai dengan rancangan strategi pembelajaran portofolio.

Setelah terpilih satu masalah dilanjutkan dengan pembagian kelompok portofolio dengan tugas masing-masing yang spesifik, yakni kelompok portofolio 1 bertugas menjelaskan masalah, kelompok portofolio 2 mengkaji kebijakan alternative untuk mengatasi masalah, kelompok portofolio 3 memilih salah satu alternative kebijakan alternative yang paling efektif dan efisien, dan kelompok portofolio 4 membuat rencana tindakan.

Dengan penerapan seluruh tahapan pembelajaran portofolio tentunya sangat memacu keaktifan dan kemampuan kerjasama siswa dalam pembelajaran. Dari sisi kuantitas memperlihatkan keaktifan dan kemampuan kerjasama siswa baru pada kategori cukup, yakni 69\% siswa terlibat secara aktif dan menjalin hubungan kerjasama yang baik dalam melaksanakan setiap tugas yang diberikan oleh guru. Namun demikian dari sisi kualitas, keaktifan dan kemampuan kerjasama 
siswa perlu ditingkatkan, mengingat pada siklus pertama ini ada beberapa hal yang perlu diperbaiki berdasarkan hasil refleksi dan dan evaluasi tim peneliti, yaitu kemampuan guru mengarahkan siswa dalam mengangkat tema permasalahan yang lebih focus pada kompetensi dasar, tugas masing-masing kelompok portofolio yang bahasanya masih membingungkan baik oleh guru maupun siswa, bahasan dan pertanyaan siswa yang tidak focus sesuai tugas masing-masing kelompok, sehingga menimbulkan munculnya pertanyaan dan jawaban yang sama disampaikan oleh kelompok yang berbeda. Hal seperti ini ternyata menimbulkan protes dari banyak kelompok yang mengakui pertanyaan atau jawaban yang sama tersebut adalah miliknya.

Kekurangan-kekurangan yang terjadi sebagaimana di atas tentunya masih wajar, mengingat pembelajaran portofolio pertama kali diterapkan oleh guru di SDN 16 Mataram, khususnya di kelas VI. Kekurangan-kekurangan tersebut dijadikan dasar dalam merencanakan dan melaksanakan tindakan pada siklus berikutnya sehingga dengan penerapan strategi pembelajaran portofolio dapat meningkatkan keaktifan dan kemampuan kerjasama siswa SDN 16 Mataram kelas VI semester 1, baik secara kuantitas dan kualitas.

\section{Siklus Kedua}

Siklus kedua ini dilaksanakan mulai hari Selasa 26 September dan berakhir tanggal 14 Oktober 2017. Penerapan strategi pembelajaran portofolio pada siklus kedua dapat meningkatkan keaktifan dan kemampuan kerjasama siswa baik secara kuantitas maupun kualitas sebagaimana diharapkan. Dari sisi kuantitas memperlihatkan jumlah siswa yang terlibat secara aktif dan dapat bekerjasama dalam pembelajaran meningkat dari siklus pertama, yaitu 21 siswa dari 31 siswa (70\%) menjadi 27 dari 31 siswa $(90 \%)$ terlihat secara aktif, baik dalam mengerjakan tugas, bertanya, mengajukan pendapat maupun merespon pertanyaan siswa lain. Dari sisi kualitas, memperlihatkan keaktifan dan kemampuan kerjasama siswa pada kategori baik, yang ditunjukkan dengan kualitas pertanyaan juga tepat, jelas dan mudah dipahami seperti pertanyaan yang diajukan oleh kelompok dua terhadap kelompok 1 "mengapa tawuran kerapkali terjadi di kota kota besar", kelompok 1 kemudian menjawab " karena disebabkan oleh berbagai hal, diantaranya kurangnya pengawasan dari pihak sekolah dan instansi yang terkait.

Sementara itu terkait dengan kerjasama baik anta anggota kelompok maupun antar kelompok juga memperlihatkan kerjasama yang baik. Hal ini diperlihatkan dengan kerjasama diantara mereka dalam mengerjakan portofolio untuk setiap kelompok yang mengharuskan mereka saling bekerjasama dengan kelompok yang lain mengingat tugas masing-masing kelompok yang saling berkaitan. Selain itu kerjasama diantara anggota kelompok juga lebih intens sebab mereka menyadari bahwa untuk dapat dengan kerjasama yang baik tentunya dapat menghasilkan hasil karya yang baik pula, dan setiap kelompok berlombalomba untuk dapat memperoleh predikat terbaik mengingat hasil karya siswa dipajang di depan kelas dan dinilai oleh guru.

Dengan demikian, penerapan strategi pembelajaran portofolio pada siklus kedua telah dapat mencapai target yang diharapkan, yakni peningkatan keaktifan dan kemampuan kerjasama siswa, baik secara kuantitas maupun kualitas sebagaimana diharapkan. Oleh karenanya berdasarkan hasil refleksi dan evaluasi yang dilakukan, tim peneliti menyepakati bahwa tindakan dirasakan cukup mengingat sudah mencapai target yang diharapkan.

Sesuai dengan tujuan pertama dalam penelitian sebagaimana yang dirumuskan yaitu menemukan upaya peningkatan kemampuan guru dalam mengelola pembelajaran melalui implementasi strategi pembelajaran portofolio sebagai strategi utama, maka penelitian tindakan kelas ini telah berhasil menemukan upaya tersebut. Melalui upaya yang sistematis pada setiap siklus menunjukkan peningkatan kemampuan guru dalam mengelola pembelajaran.

Berdasarkan hasil pengolahan data siklus I dan siklus II terjadi peningkatan prosentase tingkat kemampuan guru dalam mengelola kegiatan pembelajaran. Jika pada siklus I, prosentase skenario pembelajaran menunjukkan ketercapaian pada kategori cukup baik, hal ini disebabkan oleh masih terbiasanya guru dalam menggunakan pendekatan pembelajaran konvensional yang berorientasi pada penguasaan materi secara kognitif sehingga siswa lebih banyak belajar untuk menghafal. Berdasarkakan data yang didapat, terjadi peningkatan rata-rata kemampuan guru 
dalam mengelola kegiatan pembelajaran pada siklus 2, baik pada tahap persiapan, pelaksanaan, pengelolaan waktu, dan pengelolaan kelas. Hal ini berarti pula bahwa indicator kinerja yang ditetapkan pada asfek kemampuan guru dalam mengelola kegiatan pembelajaran telah terpenuhi.

Peningkatan tersebut tidak lepas dari pembenahan dilakukan pada scenario pembelajaran meliputi pembenahan dalam pengelolaan pembelajaran yang lebih berpihak pada pengalaman belajar siswa. Penyesuaian dengan alokasi waktu, pembenahan pola pembentukan kelompok yaitu dengan memperhatikan pola kerjasama pada siklus 2, pola pelibatan siswa dalam presentasi, penyenpurnaan setting pembelajaran merupakan upaya yang efektif dalam meningkatkan kemampuan guru dalam mengelola pembelajaran.

Selama proses pembelajaran pada siklus2, guru sudah antusias, lebih santai, lebih variatif, tidak ragu-ragu dalam mengelola kegiatan pembelajaran, dan memiliki kepercayaan diri sehingga lebih mudah dalam membimbing dan mengkondisikan siswa untuk belajar. Di samping itu, perubahan terhadap skenario pembelajaran pada setiap siklus turut memberikan kontribusi dalam upaya memusatkan perhatian siswa, merangsang keberanian siswa yang berkemampuan rendah untuk bertanya, mengungkapkan pendapat atau pikirannya. Kepercayaan diri dan kemandirian siswa semakin meningkat dengan adanya kontrak belajar yang jelas sehingga cukup bersemangat untuk mengikuti pelajaran dibandingkan dengan siklus pertama. Hal tersebut menunjukkan bahwa strategi pembelajaran portofolio sebagai strategi utama cukup efektif dalam memperbaiki dan meningkatkan kinerja professional guru. Adanya pemahaman dan kemampuan guru dalam mengembangkan rancangan pembelajaran, pengelolaan proses pembelajaran, pengelolaan kelas hingga tercapainya optimalisasi keaktifan belajar siswa merupakan dampak pengiring dari implementasi pembelajaran portofolio dalam bentuk penelitian tindakan kelas. Penyempurnaanpenyempurnaan yang dilakukan selama praktik pembelajaran yang sesuai dengan kondisi kelas merupakan bentuk latihan dalam bentuk unjuk kerja, melakukan refleksi, selanjutnya melakukan perbaikan.

Sesuai dengan tujuan penelitian yang kedua sebagaimana yang dirumuskan, yaitu menemukan upaya peningkatan keaktifan belajar selama proses pembelajaran dan aktivitas siswa dalam belajar kelompok pada mata pelajaran PKn melalui penerapan strategi pembelajaran portofolio sebagai strategi utama, maka penelitian tindakan ini telah berhasil menemukan upaya tersebut. Keberhasilannya dinyatakan berdasarkan adanya peningkatan keaktifan siswa selama proses pembelajaran. Rekapitulasi hasil dalam setiap siklus terlampir.

Penerapan strategi pembelajaran portofolio efektif meningkatkan keaktifan siswa dalam proses pembelajaran. Hasil penelitian ini menunjukkan pula terwujudnya dampak instruksional meliputi tidak hanya peningkatan intelektual (dalam wujud produk hasil belajar), melainkan juga keaktifan siswa selama proses pembelajaran. Kenyataan ini ditunjukkan dengan keseriusan siswa dalam menyelesaikan tugas kelompok, berlatih keterampilan/kerjasama kelompok, dan keaktifan serta kreativitas dalam menjelaskan hasil kerja/presentasi. Berdasarkan data yang didapat, dengan jelas menggambarkan peningkatan yang pada setiap kategori keaktifan siswa.

Rendahnya capaian pada siklus I tidak lepas dari masih dominannya guru dalam pembelajaran sehingga aktivitas siswa dalam proses pembelajaran belum optimal. Pembenahan yang dilakukan pada scenario dan implementasi pembelajaran seperti pembenahan terhadap alokasi waktu, pembenahan pola pembentukan kelompok yaitu dengan memperhatikan pola kerjasama pada siklus 2, penyempurnaan pada tekhnik pembelajaran yaitu dengan membuat kontrak belajar berupa kriteria kerja kelompok, presentasi kelompok, dan produk hasil belajar, pola pelibatan siswa dalam presentasi, memberikan kontribusi yang cukup baik terhadap peningkatan aktivitas siswa selama proses pembelajaran.

Berdasarkan indikator keberhasilan yang ditetapkan, yaitu penelitian dinyatakan berhasil jika keaktifan siswa meningkat dibandingkan sebelum tindakan. Secara kuantiitatif dinyatakan berhasil jika keseluruhan unsur keaktifan siswa yang ditetapkan pada kategori baik. Berdasarkan hasil pemantauan secara kolaboratif antar tim peneliti, dari berbagai kegiatan siswa dan guru dalam proses pembelajaran dapat dinyatakan bahwa: sebelum tindakan, proses pembelajaran lebih didominasi oleh guru dengan metode ceramah dan diskusi kelas. Kadar keaktifan guru dalam melaksanakan pembelajaran terfokus pada kegiatan 
menyampaikan materi pelajaran. Dalam proses pembelajaran siswa lebih banyak pasif (mendengarkan dan mencatat saja) daripada aktif.

Keaktifan siswa pada kegiatan awal pembelajaran kemudian dibandingkan dengan setelah tindakan yaitu dengan menerapkan strategi pembelajaran portofolio, ternyata siswa sangat antusias mengikuti pembelajaran. Siswa terlihat lebih aktif terutama pada pelaksanaan siklus 2 . Hasil observasi dengan menggunakan lembar observasi menunjukkan tingkat capaian pada siklus tersebut pada kategori baik. Ini artinya bahwa tindakan kelas yang dilakukan guru dengan menggunakan strategi pembelajaran portofolio dinyatakan berhasil, karena telah memenuhi standar minimal (indicator keberhasilan/kinerja) yang ditetapkan. Hal ini juga berarti bahwa pemeblajaran portofolio sangat akomodatif dalam menawarkan berbagai kesempatan bagi siswa untuk terlibat dalam pembelajaran, misalnya guru dan siswa melakukan curah pendapat, aktif dalam kegiatan diskusi kelompok maupun presentasi kelas. Hal ini berarti bahwa strategi pembelajaran portofolio juga cukup efektif dalam meningkatkan sktivitas mental dan social siswa selama proses pembelajara.

Keberanian dan kualitas pertanyaan, kemampuan dalam menyampaikan gagasan, toleransi terhadap argument atau pendapat temannya, dan selalu mengerjakan tugas yang menjadi tanggung jawabnya merupakan proses mental dan sosisal yang berkembang yang dapat membantu dan membentuk pengetahuan dalam diri siswa. Jika dikaitkan dengan indicator kinerja yang ditetapkan bahwa jika terjadi peningkatan keterampilan kerjasama setelah tindakan, maka penelitian tindakan kelas yang menggunakan pembelajaran portofolio dibuktikan efektif dan berhasil dilihat dari peningkatan keterampilan kerjasama siswa.

\section{Kesimpulan}

Berdasarkan hasil tindakan kelas yang dilakukan dapat disimpulkan bahwa penerapan strategi pembelajaran portofolio dapat meningkatkan keaktifan dan kemampuan kerjasama siswa kelas VI semester 1 SDN 16 Mataram pada mata pelajaran Pendidikan Kewarganegaraan (PKn) yang diperlihatkan dengan kemampuan sebagian besar siswa dalam mengajukan pertanyaan, memberikan respon, mengajukan gaagsan, mengumpulkan data, serta membuat portofolio dokumen dan portofolio tayangan dengan kerjasama yang intens, baik antar anggota kelompok maupun antar kelompok dengan kualitas yang baik.

\section{Saran}

Berdasarkan hasil penelitian ini, disarankan kepada para guru yang membina mata pelajaran PKn untuk dapat memilih dengan cermat suatu pendekatan pembelajaran yang tepat sesuai karakter mata pelajaran dan kompetensi yang diharapkan dapat dicapai siswa sehingga memudahkan guru dalam membantu siswa mencapai kompetensi yang pada gilirannya dapat mencapai apa yang menjadi harapan dalam pemberian mata pelajaran $\mathrm{PKn}$ melalui keterlibatan siswa secara aktif dalam pembelajaran dan kemampuan para siswa dalam bekerjasama mengerjakan setiap tugas yang diberikan.

\section{Daftar Pustaka}

Azra. Azzumardi. (2003). Pendidikan Kewarganegaraan. Jakarta. Prenada media.

Depdiknas RI. (2006). Kurikulum PKn SD. Jakarta. Depdiknas RI

Winataputra. Udin S. (2003). Materi dan Pembelajaran PKn SD. Jakarta. Universitas Terbuka.

Kemmis, S \& Mc Taggart, R. 1992.The Action Research Planner. Australia: Deakin University Press.

Miles, M.B \& Huberman A.M. 1984. Analisis Data Kualitatif. Terjemahan oleh Tjetjep Rohendi Rohidi. 1992. Jakarta: Penerbit Universitas Indonesia. 